\title{
PLANKTON SEBAGAI INDIKATOR PENCEMARAN PERAIRAN DI KAWASAN PELABUHAN YANG DIJADIKAN TEMPAT PENDARATAN IKAN DI BALI
}

\author{
PLANKTON AS A WATER POLLUTION INDICATOR \\ IN THE PORT AREA THAT MAKES \\ FISHING LAND PLACE IN BALI
}

\author{
Albertus Guntur Arsetyanto Labupili ${ }^{1}$, Ita Junita Puspa Dewi*1 dan Firman Agus \\ Heriansyah $^{2}$ \\ ${ }^{1}$ Teknologi Pengelolaan Sumberdaya Perairan, Sekolah Tinggi Perikanan Jakarta 12520, Indonesia \\ ${ }^{2}$ Teknik Kelautan, Politeknik Kelautan dan Perikanan Kerawang, Indonesia \\ * Korespondesi Penulis: ita.dewi@kkp.go.id
}

Diterima: 12 November 2018; diterima setelah perbaikan: 11 November 2018; Disetujui: 11 November 2018

\begin{abstract}
ABSTRAK
Pelabuhan yang dijadikan tempat pendaratan ikan adalah tempat dimana semua kegiatan perikanan ada di dalamnya. Aktifitas di pelabuhan dapat menyebabkan kualitas perairan menjadi buruk. Oleh karena itu, dibutuhkan pengamatan yang ditinjau dari struktur komunitas plankton dan kualitas perairan. Pengamatan ini dilaksanakan pada tanggal Januari sampai Juni 2017 di Pelabuhan Pengambengan, Benoa dan Amed.

Hasil pengamatan menunjukkan bahwa komposisi fitoplankton yang ditemukan adalah 16 genera dari 3 kelas. Untuk zooplankton ditemukan 6 genera dari 4 kelas. Indeks biologi plankton (fitoplankton dan zooplankton) yang didapat, untuk indeks keanekaragaman $\left(\mathrm{H}^{\prime}\right)=1.22$, indeks keseragaman $(\mathrm{E})=0.91$, indeks dominansi $(C)=0.36$. Hasil indeks saprobik dan tropik saprobitas indeks berkisar pada 0.156-0.208 dan 0.1010.123. Berdasarkan kriteria, kualitas perairan di pelabuhan yang dijadikan tempat pendaratan ikan di Bali untuk skala besar (>30 GT) tergolong dalam tercemar ringan, untuk skala menengah (10-30 GT) tergolong dalam tercemar sedang, dan untuk skala kecil $(<10 \mathrm{GT})$ tergolong dalam memenuhi standar.
\end{abstract}

Kata Kunci : Plankton, Pencemaran,Indikator, Perairan, Bali

ABSTRACT

The harbor that used as a fish landing site is the place for all kinds of activities related to fisheries. Activities in the port will cause the quality of port water to be bad. Therefore, it is necessary to observe that the port is polluted through observation of plankton community structure and water quality. This observation took place from January to June 2017 at Pengambengan, Benoa and Amed Port.

The observations for the phytoplankton composition showed that 16 genera were found 3 classes. For the zooplankton were found 6 genera of 4 classes. The plankton biological indexes (phytoplankton and zooplankton) were obtained in a row, ie, the index of diversity $\left(H^{\prime}\right)=1.22$, uniformity index $(E)=0.91$, dominance index $(C)=0.36$. The results showed saprobic index and tropical saprobic plankton index ranged from 0.156-0.208 and 0.101-0.123. Based on these criteria, the water quality at the port used as a fish landing site in Bali for large-scale ports (> 30 GT) are classified as lightly polluted, medium-sized ports (10-30 GT) are moderately polluted, and small-scale ports $(<10 \mathrm{GT})$ is classified as quality standard.

Keywords: Plankton, Pollution, Indicators, Waters, Bali

Copyright (C) Jkpt Juni 2018

Plankton Sebagai Indikator Pencemaran Perairan.........Dewi, et.al 


\section{PENDAHULUAN}

Sumberdaya pesisir dan lautan menjadi alternatif untuk pembangunan masa depan Indonesia, karena memiliki potensi yang besar untuk dikembangkan baik dari sisi ekonomis maupun ekologis. Pada wilayah seperti ini terdapat berbagai jenis biota perairan yang bernilai ekonomis penting maupun tidak. Salah satu jenis biota yang penting dan mempunyai peranan besar di perairan adalah plankton (Yuliana, 2015).

Plankton merupakan semua kumpulan organisme air, baik hewan maupun tumbuhan yang berukuran mikroskopis dan hidupnya melayang mengikuti arus (Nontji, 2008). Plankton terdiri atas fitoplankton yang merupakan produsen utama (primary producer) zat-zat organik dan zooplankton yang tidak dapat memproduksi zat-zat organik, sehingga harus mendapat tambahan bahan organik dari makanannya (Yuliana et al., 2012). Fitoplankton mempunyai peranan yang sangat penting di dalam perairan, selain sebagai dasar dari rantai makanan (primary producer) juga merupakan salah satu parameter tingkat kesuburan suatu perairan (Mujiyanto et al., 2011). Keberadaan fitoplankton sangat diperlukan dalam menjaga kelangsungan hidup ekosistem perairan dan memegang peranan penting dalam mata rantai makanan (Sachoemar \& Hendiarti, 2006). Dominasi suatu jenis fitoplankton pada badan air ditentukan oleh perbandingan jenis nutrien yang telarut dalam badan air. Hal ini disebabkan setiap jenis fitoplankton mempunyai respon yang berbeda terhadap pebandingan jenis nutrien yang ada terutama nitrogen dan fosfor dalam badan air (Barus, 2004). Kelimpahan fitoplankton memiliki hubungan positif dengan produktivitas perairan. Jika kelimpahan fitoplankton disuatu perairan tinggi maka perairan tersebut cenderung memiliki produktivitas yang tinggi pula. Meskipun lokasi pengamatan relatif berdekatan dan berasal dari massa air yang sama, namun berbagai faktor seperti angin, arus, suhu, kedalaman dan pencampuran massa air menyebabkan adanya perbedaan Copyright @ Jkpt Juni 2018

Plankton Sebagai Indikator Pencemaran Perairan.......Dewi, et.al kandungan fitoplankton (Yuliana et al., 2012).

Bali merupakan salah satu pulau yang memiliki 11 Pelabuhan Perikanan. Pelabuhan Perikanan (PP) adalah pusat aktivitas perekonomian kelautan, sehingga keberadaannya sangat diperlukan dalam pembangunan perikanan dan kelautan (Suherman, 2011). Pelabuhan Perikanan Nusantara (PPN) Pengambengan merupakan salah satu pelabuhan perikanan Bali yang berada di daerah Jembrana yang menampung kegiatan masyarakat perikanan, terutama terhadap aspek produksi, pengolahan dan pemasaran, serta pembinaan masyarakat nelayan (Suherman \& Dault, 2009). Disekitar kawasan PPN Pengambengan terdapat 9 perusahaan pengalengan dan penepungan ikan, dengan tingkat produksi mencapai 13.821 ton/tahun (Poppo, 2008). Buana (2013) melaporkan bahwa umumnya perusahaan tersebut belum memiliki Instalasi Pengolahan Air Limbah (IPAL) yang standar. Pelabuhan Perikanan terbesar kedua di Bali yaitu Pelabuhan Benoa Bali. Pelabuhan ini merupakan pelabuhan utama di Bali yang menjadi basis pangkalan pendaratan ikan tuna di Indonesia (Nugraha \& Hufiadi, 2013 dan Swastana et al., 2016). Pelabuhan Benoa dikelilingi oleh beberapa perusahaan dan tempat pariwisata seperti Tanjung Benoa. Selain itu bukan hanya kapal ikan yang berada di sekitar Pelabuhan Benoa, tetapi terdapat juga kapal pesiar dan kapalkapal yang lain (Nugraha \& Hufiadi, 2013).

Berdasarkan kondisi dan tempat keberadaan Pelabuhan Perikanan di Bali yang dekat dengan aktifitas perindustrian, perusahaan dan tempat pariwisata, bisa diduga perairan di sekitar wilayah pelabuhan telah tercemar. Penelitian ini bertujuan untuk mengindentifikasi komposisi plankton dan mengetahui struktur komunitasnya, mengetahui kondisi perairan, tingkat pencemaran perairan, dan status mutu perairan yang berada di kawasan pelabuhan perikanan. 


\section{BAHAN DAN METODE}

Penelitian dilaksanakan pada Januari 2017 sampai Juni 2017, dengan pengambilan sampel plankton di Pelabuhan Perikanan di Bali (Pengambengan, Benoa dan Amed). Sedangkan analisis laboratorium akan dilakukan di Laboratorium Balai Penelitian dan Observasi Laut (BPOL) Bali dan UPT Laboratorium Analitik,

\section{Metode Pengumpulan Data}

Sumber data yang dipergunakan dalam penelitian ini meliputi data-data primer dan sekunder. Data primer adalah data yang diperoleh secara langsung dari sumber pertama, yang terdiri dari data air limbah dan air laut meliputi : parameter fisika, kimia dan biologi (Poppo et.al, 2008). Sedangkan data sekunder yaitu data yang diperoleh dari sumber kedua berupa data dari Dinas Lingkungan Hidup Provinsi Bali (literatur, laporan, dan jurnal) yang berkaitan dengan penelitian.

\section{Penentuan Lokasi Pengamatan}

Penentuan lokasi pengamatan dilakukan dengan metode "Purpossive Sampling" penentuan lokasi berdasarkan atas adanya tujuan tertentu dan sesuai dengan pertimbangan peneliti sendiri sehingga mewakili populasi (Hidayat et.al., 2013). Yaitu dengan menentukan 4 stasiun pengukuran di pelabuhan. Stasiun yang diamati yaitu stasiun yang dianggap bisa mewakili badan air yang diamati. Penentuan titik dipilih berdasarkan tempat yang dianggap penting. Dan Penentuan stasiun lokasi pengambilan sampel menggunakan GPS (Global Postioning System).

\section{Pengambilan Sampel}

Pengambilan sampel plankton dilakukan pada siang hari dimana telah terdapat sinar matahari, karena pada saat itu fitoplankton akan melakukan proses fotosintesis. Sampel air diambil dari permukaan air (secara horizontal) menggunakan ember 10 liter kemudian disaring menggunakan plankton net dan dilakukan secara berulang 10 kali. Sampel plankton hasil penyaringan sebanyak $100 \mathrm{ml}$ dan diawetkan dengan formalin $\mathbf{4 \%}$ (3 tetes) kemudian diberi larutan lugol (3

Copyright (C) Jkpt Juni 2018

Plankton Sebagai Indikator Pencemaran Perairan tetes) untuk mewarnai plankton. Selanjutnya dianalisa di Laboratorium.

\section{Pengukuran Parameter Kualitas Air}

Pada saat pengukuran parameter kualitas perairan diperlukan kecermatan dan berhatihati saat pengambilan sampel. Pengambilan sampel juga harus bersifat keterwakilan atas tujuan dilaksanakan praktik ini. Pencatatan keadaan atau cuaca saat pengukuran parameter kualitas air juga diperlukan untuk memperkuat data yang diambil. Parameter kualitas air yang diamati adalah parameter fisika (arus, kecerahan, suhu, dan salinitas) dan parameter kimia ( $\mathrm{pH}, \mathrm{DO}$, amonia, nitrat, nitrit, fosfat, dan timbal).

\section{Identifikasi Plankton}

Sampel air yang telah didapat sebanyak $100 \mathrm{ml}$ diamati dengan mikroskop di laboratorium. Adapun langkah kerjanya sebagai berikut:

a. Air dalam botol sampel digoyanggoyangkan untuk menjaga homogenitas plankton di dalamnya

b. Sampel air dituangkan ke dalam Sedgewick rafter cell menggunakan pipet tetes

c. Pengamatan dilakukan secara mikroskopis menggunakan mikroskop binokuler dengan pembesaran 100x

d. Pemotretan dilakukan dengan mengsave gambar plankton yang terlihat pada layar LCD agar gambar dapat didapat lebih jelas untuk diamati, bahkan bisa diamati di rumah

e. Identifikasi plankton dengan menggunakan buku Edhy et al. (2003) dan Yamaguchi \& Gould (2007)

\section{Analisis Data}

\section{Kelimpahan plankton}

Kelimpahan plankton dihitung untuk mengetahui jumlah individu atau satu sel per satuan volume (liter), sehingga dapat mengetahui tingkat kepadatan plankton di suatu perairan (Choirun et al., 2015). Penentuan kelimpahan plankton dihitung menggunakan rumus APHA (1989) dalam Radiarta (2013), sebagai berikut :

$$
\mathrm{N}=\frac{\mathrm{Oi}}{\mathrm{Op}} \times \frac{\mathrm{Vr}}{\mathrm{Vo}} \times \frac{1}{\mathrm{Vs}} \times n
$$


Keterangan :

$\mathrm{N} \quad=$ Jumlah sel per liter (sel/l)

Oi $\quad=$ Luas gelas penutup preparat $\left(\mathrm{mm}^{2}\right)$

$\mathrm{p} \quad=$ Jumlah lapang pandang yang teramati

\section{Indeks Keanekaragaman $\left(\mathrm{H}^{\prime}\right)$}

Indeks keanekaragaman merupakan penggambaran secara matematik yang melukiskan struktur komunitas plankton untuk menganalisa informasi-informasi tentang jenis dan jumlah plankton di suatu perairan. Perhitungan indeks keanekaragaman plankton dilakukan dengan menggunakan Indeks Shannon-Wiener dalam Wijiyono dan Artiningsih (2013), sebagai berikut :

$$
\mathrm{H}^{\prime}=\sum_{\mathrm{i}=1}^{\mathrm{S}} \mathrm{pi} \ln \mathrm{pi}
$$

$$
\text { , dimana } \mathrm{pi}=\frac{\mathrm{ni}}{\mathrm{N}}
$$

Keterangan :

$\mathrm{H}^{\prime}=$ Indeks keanekaragaman jenis

pi $=$ Proporsi kelimpahan dari jenis plankton ke-i (ni/N)

$\mathrm{ni}=$ Jumlah individu jenis plankton ke-i

$\mathrm{N}$ = Jumlah total individu plankton

Indeks Keseragaman (E)

Indeks keseragaman digunakan untuk menunjukan sebaran plankton dalam suatu komunitas. Indeks keseragaman data dihitung dengan formula sebagai herikut ( Yuliana. 2014):

Keterangan :

$\mathrm{E} \quad=$ Indeks keseragaman

H' = Indeks keanekaragaman Shannon-Wiener

$\mathrm{H}_{\max } \quad=\operatorname{lns}$ (indeks keanekaragaman maksimum)

$\mathrm{s} \quad=$ Jumlah genus yang ditemukan

\section{Indeks Dominansi (C)}

Indeks dominansi digunakan untuk melihat ada tidaknya suatu jenis plankton tertentu yang mendominasi dalam suatu jenis populasi (Choirun el al., 2015). Perhitungan indeks dominansi dapat menggunakan indeks dominansi Simpson dalam Pirzan dan Petrus (2008), dengan persamaan berikut:

$$
\mathrm{C}=\sum_{\mathrm{i}=1}^{\mathrm{s}}(\mathrm{pi})^{2}
$$

Keterangan :

$\mathrm{C} \quad=$ Indeks dominansi

pi $\quad=\frac{n i}{N}=$ proporsi spesies ke-i

\section{Saprobik Indeks (SI) dan Tingkat Saprobik Indeks (TSI)}

Untuk menghitung saprobitas perairan digunakan analisis trosap yang nilainya ditentukan dari Saprobik Indeks (SI) dan Tropik Saprobik Indeks (TSI). Formula yang digunakan adalah hasil formulasi Zahidin (2008) dan Wijaya \& Riche (2011):

Keterangan:

$$
\mathrm{SI}=\frac{1 \mathrm{C}+3 \mathrm{D}+1 \mathrm{~B}-3 \mathrm{~A}}{1 \mathrm{~A}+1 \mathrm{~B}+1 \mathrm{C}+1 \mathrm{D}}
$$

SI = Saprobik Indeks

Copyright @ Jkpt Juni 2018

Plankton Sebagai Indikator Pencemaran Perairan.......Dewi, et.al 
A = Jumlah Spesies Organisme Polisaprobik

$\mathrm{B}=$ Jumlah Spesies Organisme $\alpha$-Mesosaprobik

$\mathrm{C}=$ Jumlah Spesies Organisme $\beta$-Mesosaprobik

Keterangan:

$$
\mathrm{TSI}=\frac{1(\mathrm{nC})+3(\mathrm{nD})+(\mathrm{nB})-3(\mathrm{nA})}{1(\mathrm{nA})+3(\mathrm{nB})+1(\mathrm{nC})+1(\mathrm{nD})} \times \frac{\mathrm{nA}+\mathrm{nB}+\mathrm{nC}+\mathrm{nD}+\mathrm{nB}}{\mathrm{nA}+\mathrm{nB}+\mathrm{nC}+\mathrm{nD}}
$$

$\mathrm{nA}=$ Jumlah individu penyusun kelompok Polisaprobik

$\mathrm{nB}=$ Jumlah individu penyusun kelompok $\alpha$-Mesosaprobik

$\mathrm{nC} \quad=$ Jumlah individu penyusun kelompok $\beta$-Mesosaprobik

$\mathrm{nD}=$ Jumlah individu penyusun kelompok Oligosaprobik

$\mathrm{nE} \quad=$ Jumlah individu penyusun selain $\mathrm{A}, \mathrm{B}, \mathrm{C}$ dan $\mathrm{D}$

\section{Metode STORET}

Metode storet merupakan salah satu metode untuk menentukan status mutu air yang umum digunakan. Dengan menggunakan metode Storet ini dapat diperoleh apakah suatu perairan melampaui baku mutu air atau tidak. Secara prinsip metodenya adalah membandingkan data kualitas air dengan baku mutu air yang disesuaikan dengan peruntukannya guna menentukan status mutu air (Fakhrunnisa, 2015). Penentuan sistem penilaian untuk menentukan status mutur air tertera pada Tabel 1.

Tabel 1. Penentuan Sistem Nilai untuk Menentukan Status Mutu Air Table 1. Determination of Value Systems for Determining Status of Water Quality

\begin{tabular}{|l|l|l|l|l|}
\hline \multirow{2}{*}{$\begin{array}{l}\text { Jumlah } \\
\text { Contoh }\end{array}{ }^{1)}$} & Nilai & Parameter & \multicolumn{2}{l|}{} \\
\cline { 3 - 5 } & & Fisika & Kimia & Biologi \\
\hline$<10$ & Maksimum & -1 & -2 & -3 \\
\cline { 2 - 5 } & Minimum & -1 & -2 & -3 \\
\cline { 2 - 5 } & Rata-rata & -3 & -6 & -9 \\
\hline \multirow{3}{*}{$\geq 10$} & Maksimum & -2 & -4 & -6 \\
\cline { 2 - 5 } & Minimum & -2 & -4 & -6 \\
\cline { 2 - 5 } & Rata-rata & -6 & -12 & -18 \\
\hline
\end{tabular}

Catatan : ${ }^{1)}$ jumlah parameter yang digunakan untuk penentuan status mutu air

Sumber : Keputusan Menteri Negara Lingkungan Hidup No. 115 Tahun 2003

Setelah diperoleh hasil status mutu air, kemudian diklasifikasikan dengan Tabel 2.

Tabel 2. Klasifikasi Nilai Indeks STORET

Table 2. Classification of STORET Index Values

\begin{tabular}{|l|l|l|}
\hline Kelas & Skor & Keterangan \\
\hline A & 0 & Memenuhi baku mutu \\
\hline B & $-1 \mathrm{~s} / \mathrm{d}-10$ & Cemar ringan \\
\hline C & $-11 \mathrm{~s} / \mathrm{d}-30$ & Cemar sedang \\
\hline D & $\geq-31$ & Cemar berat \\
\hline
\end{tabular}

Sumber : Keputusan Menteri Negara Lingkungan Hidup No. 115 Tahun 2003

Copyright $@$ Jkpt Juni 2018

Plankton Sebagai Indikator Pencemaran Perairan........Dewi, et.al 


\section{HASIL DAN PEMBAHASAN}

Komposisi fitoplankton yang ditemukan selama pengamatan pada ketiga pelabuhan dengan karakterisitik stasiun yang sama didapatkan 3 kelas dengan 16 genera, dimana kelas Bacillariophyceae terdiri dari 11 genera, kelas Cyanophyceae terdiri dari 3 genera, dan Dinophyceaea terdiri dari 2 genera. Komposisi zooplankton yang ditemukan selama pengamatan pada ketiga pelabuhan didapatkan 4 kelas dengan 6 genera, dimana kelas Crustaceae (2 genera), Cilliata (2 genera), Annelida ( 1 genera) dan Monogonanta (1 genera).

Kelimpahan rerata plankton (fitoplankton dan zooplankton) selama pengamatan dapat diketahui bahwa kelimpahan fitoplankton tertinggi terdapat pada kawasan pelabuhan Amed dengan nilai berkisar $1384 \mathrm{sel} / \mathrm{L}(44,78 \%)$ dan untuk zooplankton terdapat pada Pelabuhan Pengambengan dengan nilai berkisar 217 individu/L $(34,93 \%)$.

Nilai keanekaragaman plankton tertinggi berada pada Pelabuhan Amed (Stasiun I) dengan kisaran nilai 1,67. Hal ini diduga karena pada Pelabuhan Amed (Stasiun I) memiliki kualitas air yang mendukung untuk kehidupan plankton. Menurut Yuliana (2015), tinggi-rendahnya suatu keanekaragaman plankton disebabkan oleh kualitas air yang baik atau tidak. Stasiun I pada Pelabuhan Amed memiliki kualitas air yang baik daripada stasiun lainnya. Selain kualitas air yang baik, arus dan intensitas cahaya pada stasiun tersebut cocok untuk kehidupan plankton. Plankton dapat hidup apabila ada arus dan intensitas cahaya yang cukup (Nontji, 2008 dan Yuliana, 2015).

Sementara nilai keanekaragaman terendah terdapat pada Pelabuhan Pengambengan (Stasiun III) dengan kisaran nilai 0,62. Hal ini diduga karena stasiun tersebut terletak pada kolam pelabuhan, sehingga tidak adanya arus. Selain itu kualitas air yang berada di stasiun tersebut dikategorikan buruk, karena terdapat logam berat dan nutrien yang berlebih. Hal ini yang menyebabkan keanekaragaman plankton pada daerah ini sangat rendah. Menurut Barus (2004) keanekaragaman yang rendah merupakan salah satu faktor penyebab sedikitnya jenis ikan dengan jumlah populasi yang relatif rendah untuk dapat hidup.

Berdasarkan kriteria keanekaragaman plankton, dapat diketahui bahwa rerata indeks keanekaragaman fitoplankton di 3 pelabuhan tergolong sedang $(1,60)$. Sedangkan untuk rerata indeks keanekaragaman zooplankton tergolong rendah $(0,84)$. Jika keanekaragaman plankton (fitoplankton dan zooplankton) dihubungkan dengan tingkat pencemaran, maka Pelabuhan Bali tergolong dalam pelabuhan yang memiliki kriteria pencemaran tercemar sedang $(1,22)$.

Kisaran indeks keseragaman plankton (fitoplankton dan zooplankton) pada setiap stasiun adalah 0,66-1,00. Berdasarkan kriteria Karuwal (2015), rerata indeks keseragaman plankton di Pelabuhan Perikanan Bali tergolong tinggi $(0,91)$. Menurut Munthe (2012), nilai indeks keseragaman yang mendekati nol cenderung menunjukan komunitas yang tidak stabil, sedangkan jika nilai indeks keseragaman mendekati satu menandakan komunitas dalam keadaan stabil. Diduga plankton di sekitar pelabuhan perikanan Bali dalam keadaan komunitas yang stabil.

Kisaran indeks dominansi pada setiap stasiun adalah 0,13-0,56. Nilai indeks dominansi zooplankton tertinggi berada pada stasiun III di Pelabuhan Amed (0,55), yang didominasi oleh genus Naupli Copepoda. Sedangkan untuk fitoplankton berada pada stasiun III di Pelabuhan Pengambengan $(0,61)$, yang didominasi oleh genus Oscillatoria sp. Hal itu diduga karena adanya individu yang mendominasi pada stasiun tersebut. Sementara itu, nilai indeks dominansi terendah berada pada stasiun I pelabuhan Amed (Fitoplankton) dan stasiun IV di Pelabuhan Benoa (Zooplankton). Hal itu diduga karena pada stasiun tersebut memiliki total individu yang hampir sama pada masing-masing genera.

Rerata indeks dominansi plankton (fitoplankton dan zooplankton) di Pelabuhan Perikanan Bali tergolong berdominansi rendah $(0,36)$. Diduga bahwa di Pelabuhan Perikanan Bali tidak terdapat genus plankton yang secara ekstrim mendominasi genus 
lainnya. Menurut pendapat Pirzan dan Petrus (2008), apabila nilai dominansi mendekati nilai 1 berarti di dalam komunitas terdapat genus yang mendominansi genus lainnya, sebaliknya apabila mendekati nilai 0 berarti di dalam struktur komunitas tidak terdapat genus yang secara ekstrim mendominasi genus lainnya.

Tingkat pencemaran Pelabuhan Perikanan di Bali terindikasi dalam pencemaran sedang sampai berat ( $\alpha$-Mesosaprobik). Menurut Zahidin (2008) ciri struktur komunitas yang tergolong dalam $\alpha$-Mesosaprobik yaitu:

1. Muncul fitoplankton yang terdiri dari Diatom (Bacillariophyceae), Cyanophyceae dan Blue Green Algae; dan

2. Jumlah produsen mulai menurun

Dari ketiga pelabuhan di Bali yang masih memenuhi baku mutu adalah Pelabuhan Amed, sedangkan Pelabuhan Pengambengan adalah pelabuhan yang dikategorikan paling tercemar, sebab banyak parameter yang melebihi ambang batas baku mutu. Berdasarkan hasil analisis data menggunakan metode Storet mengacu pada standar baku mutu Keputusan Menteri Lingkungan Hidup No. 51 tahun 2004 tentang baku mutu air laut untuk biota laut, air laut di Pelabuhan Perikanan Bali (Pengambengan, Benoa, dan Amed) bila dirata-rata memperoleh skor 12,67. Menurut analisis metode Storet, air laut di sekitar Pelabuhan Perikanan Bali tergolong dalam kelas $\mathrm{C}$ atau cemar sedang jika diperuntukkan untuk biota laut.

\section{KESIMPULAN}

Berdasarkan hasil pengamatan apabila ditinjau dari parameter fisika, kimia dan struktur komunitas plankton, dapat disimpulkan bahwa kualitas perairan di pelabuhan yang dijadikan tempat pendaratan ikan di Bali untuk skala besar (>30 GT) tergolong dalam tercemar ringan, untuk skala menengah (10-30 GT) tergolong dalam tercemar sedang, dan untuk skala kecil $(<10$ GT) tergolong dalam memenuhi standar.

\section{DAFTAR PUSTAKA}

Barus, T. A. (2004). Faktor-Faktor Lingkungan Abiotik dan

Keanekaragaman Plankton sebagai Indikator Kualitas Perairan Danau Toba. Manusia dan Lingkungan, Vol. XI, No. 2, Juli 2004, hal. 64-72. Link

Choirun, A., Sari, S. H. J., \& Iranawati, F. (2016). Identifikasi Fitoplankton Spesies Harmfull Algae Bloom (HAB) saat Kondisi Pasang di Perairan Pesisir Brondong, Lamongan, Jawa Timur. Torani: Jurnal Ilmu Kelautan dan Perikanan, 25(2). Link

Edhy, W. A., Pribadi, J., Kurniawan. 2003. Plankton. PT. Central Pertiwi Bahari. Tulangbawang.

Fakhrunnisa, A. (2015). Analisis Kualitas Air Laut pada Kawasan Sekitar Pelabuhan Paotere. Link

Hidayat, R., Viruly, L., TP, S., Si, M., Azizah, D., \& Pi, S. Kajian Kandungan Klorofil-a pada Fitoplankton terhadap Parameter Kualitas Air di Teluk Tanjung Pinang Kepulauan Riau. Link

Karuwal, J. W. (2015). Hubungan Parameter Fisik Perairan dengan Struktur Menegak Komunitas Plankton di Teluk Ambon Dalam. Jurnal Agroforestri X No. 1. Link

Keputusan Menteri Negara Lingkungan Hidup. (2003). Keputusan Menteri Negara Lingkungan Hidup Nomor 115 tahun 2003 tentang Pedoman Penentuan Status Mutu Air. Link

Keputusan Menteri Negara Lingkungan Hidup. (2004) Keputusan Menteri Lingkungan Hidup Nomor 51 Tahun 2004 tentang Baku Mutu Air Laut. Link

Mujiyanto, Tjahjo D. W. H., Sugianti Y. 2011. Hubungan antara Kelimpahan Fitoplankton dengan Konsentrasi N:P pada Daerah Keramba Jaring Apung 
(KJA) di Waduk Ir. H. Djuanda. LIMNOTEK 18 (1) 15-25.

Munthe, Y. V., Riris A. dan Isnaini. 2012. Struktur Komunitas dan Sebaran Fitoplankton di Perairan Sungsang Sumatera Selatan. Jurnal Maspari. Vol 4 (1) : hal 122-130.

Nontji, A. (2008). Plankton laut. Yayasan Obor Indonesia. Link

Nugraha, B. \& Hufiadi. (2012). Efisiensi Teknis Perikanan Rawai Tuna di Benoa (Studi Kasus: PT. Perikanan Nusantara). J. Lit. Perikanan Vo.1 19 No. 1: 25-30. Link

Pirzan, M. A. \& Petrus (2008). Hubungan Keragaman Fitoplankton dengan Kualitas Air di Pulau Bauluang, Kabupaten Takalar, Sulawesi Selatan. Balai Riset Perikanan Budidaya Air Payau, Maros. Jurnal Biodiversitas, 9(3), 22-217. Link

Poppo, A., Mahendra, M. S., \& Sundra, I. K. (2008). Studi Kualitas Perairan Pantai di Kawasan Industri Perikanan, Desa Pengambengan, Kecamatan Negara, Kabupaten Jembrana. Ecotrophic: Journal of Environmental Science, 3(2). Link

Radiarta, I. N. (2013). Hubungan Antara Distribusi Fitoplankton dengan Kualitas Perairan di Selat Alas, Kabupaten Sumbawa, Nusa Tenggara Barat. Link

Sachoemar, S. I., \& Hendiarti, N. (2011). Struktur Komunitas dan Keragaman Plankton Antara Perairan Laut di Selatan Jawa Timur, Bali dan Lombok. Jurnal Hidrosfir Indonesia, 1(1). Link

Suherman, A., \& Dault, A. (2009). Dampak Sosial Ekonomi Pembangunan dan Pengembangan Pelabuhan Perikanan Nusantara (PPN) Pengambengan Jembrana Bali. Jurnal Saintek Perikanan, 4(2), 24-32. Link

Suherman, A. (2011). Formulasi Strategi Pengembangan Pelabuhan Perikanan
Nusantara

Jembrana. Jurnal

Pengambengan

Fisheries, 2(1). Link

Wijaya, T. S., \& Hariyati, R. (2011). Struktur Komunitas Fitoplankton sebagai Bio Indikator Kualitas Perairan Danau Rawapening Kabupaten Semarang Jawa Tengah. Buletin Anatomi dan Fisiologi dh Sellula, 19(1). Link

Wijiyono \& Artiningsih, S. 2013. Keanekaragaman Fitoplankton Di Dalam Kolam Bioremediasi Di PTABBATAN Yogyakarta. Penelitian dan Pengelolaan Perangkat Nuklir, Pusat Teknologi Akselerator dan Proses Bahan. Link

Yamaguchi, E., \& Andy, G. (2007). Phytoplankton Identification Guide. The University of Georgia Marine Education Center and Aquarium. Link

Yuliana, Adiwilaga, E. M., Harris, E., Pratiwi, N. T. M. 2012. Hubungan antara Kelimpahan Fitoplankton dengan Parameter Fisik-Kimiawi Perairan di Teluk Jakarta. Jurnal Akuatika Vol. III No.2 (169-179). Link

Yuliana. (2014). Keterkaitan Antara Kelimpahan Zooplankton dengan Fitoplankton dan Parameter FisikaKimia di Perairan Jailolo, Halmahera Barat. Maspari Journal Volume 6, Nomor 1: 25-31. Link

Yuliana. 2015. Distribusi dan Struktur Komunitas Fitoplankton di Perairan Joilolo, Halmahera Barat. Jurnal Akuatika 4(1): 41-48. ISSN: 0853-2532. Link

Zahidin, M. 2008. Kajian Kualitas Air di Muara Sungai Pekalongan ditinjau dari Indeks Keanekaragaman Makrobenthos dan Indeks Saprobitas Plankton (Doctoral dissertation, Program Pascasarjana Universitas Diponegoro). Link 